\title{
UNDERGARMENT PPE WITH MODULAR STRUCTURE FOR STAFF WORKING IN THE NATIONAL DEFENSE, PUBLIC ORDER AND SECURITY SYSTEM
}

\author{
DOINA TOMA ${ }^{1}$, ALINA POPESCU ${ }^{1}$, CLAUDIA NICULESCU ${ }^{1}$, GEORGETA POPESCU ${ }^{1}$, \\ ADRIAN SĂLIŞTEAN ${ }^{1}$, MARCEL ISTRATE ${ }^{2}$, MARIA BUZDUGAN ${ }^{3}$, \\ MARCELA RADU ${ }^{3}$ \\ ${ }^{1}$ The National Research Development Institute for Textiles and Leather, 16 Lucretiu Patrascanu, \\ 030508 Bucharest, Romania email: certex@certex.ro \\ ${ }^{2}$ STIMPEX SA 46-48 Nicolae Teclu, 032368 Bucharest, Romania, email: \\ marcel.istrate@stimpex.ro \\ ${ }^{3}$ Magnum SX SRL 61 Ferdinand I, 021383 Bucharest, Romania, email: magsx2000@gmail.com
}

\begin{abstract}
The protection of operational staff from defense, public order, security structures, with a personal protective equipment system adequate to the conditions of execution of specific missions is a major desiderate for optimizing the efficiency of these formations. Reducing losses, increasing combativeness of fighters and the time actually dedicated to the mission are factors influenced by the quality of individual protection equipment. Underwear is the functional part of the military clothing system and it is affected by middle and outer clothing layers. Main function of the underwear is to maintain user's skin dry and improve thermal and moisture sensations on the skin. The aim of the project was to develop functional undergarment equipment, designed to be integrated in specialized protection equipment systems, in order to ensure the survival and resistance of operational staff from the defense, public order, security structures, in variable conditions of temperature, activity and weight levels of the equipment carried. The functional cellulose fibers (ex: Cell Solution Clima, Cell Solution Protection and Cell Solution Skin Care), blended with natural cellulosic fibres have been selected and used to accomplish the knitted fabrics. Prototypes of undergarment PPE which are integrated or non-integrated in specialized equipment of end users were evaluated and tested in real conditions of use.
\end{abstract}

Keywords: personal protective equipment, functional undergarment equipment, comfort

\section{INTRODUCTION}

Military activities and operations are intrinsically hazardous. Soldiers conducting full-spectrum operations must assume calculated risks every day, based on the significance of the mission, the operational requirement and opportunity.

The spectrum of hazards and threats facing dismounted soldiers include: man-made threats/ hazards: Improvised Explosive Devices, CBRNE effects, obstacles, mine fields, booby traps; operational hazards / threats: opposing military operations, insurgents, sympathizers, local population, fratricide; natural hazards / threats: weather, heat/cold, rain, sand/dust/wind, insects (Soldier Systems, 2011). Personal protective equipment (PPE) needs to remain effective and functional across a wide array of tactical requirements and operating environments - from arctic to desert temperatures, in high and low humidity, in urban, rural, forested, marine, or subterranean environments, and in almost every imaginable locations. PPE users also have a variety of mission profiles, from high visibility patrol to assault and covert operations, with the nature of threats and the acceptable risk in each scenario being varied as well. To respond to ever changing and varied threats that act on users and the variety of operating environments, PPEs need to be continually developed / upgraded.

The protection of operational staff from defense, public order, security structures, with a personal protective equipment system adequate to the conditions of execution of 
specific missions is a major desiderate for optimizing the efficiency of these formations. Reducing losses, increasing combativeness of fighters and the time actually dedicated to the mission are factors influenced by the quality of PPE. Modular garment systems are generally designed around three primary layers: a base or next-to-skin layer that is designed to wick moisture away from the body; an insulation layer that provides volume and allows warm air to be trapped between the body and the outer garment; and the outer shell layer that protects the wearer from the elements. (Project Responder 4, 2014). Underwear is the functional part of the military clothing system and it is affected by middle and outer clothing layers. Main function of the underwear is to maintain user's skin dry and improve thermal and moisture sensations on the skin and, therefore, it may significantly affect comfort sensations.

The aim of the project was to develop functional undergarments equipment, designed to be integrated in specialized protection equipment systems, in order to ensure the survival and resistance of operational staff from the defense, public order, security structures, in variable conditions of temperature, activity and weight levels of the equipment carried.

\section{EXPERIMENTAL PART}

From the analysis of the types of aggression for which protection must be ensured there were identified the performance requirements imposed by the specific European standards that were translated into properties required for manufacturing materials and constructive design parameters of undergarment PPE with modular structure integrated into specialized PPE for use in military operations/ intervention actions: a multilayer structure: undergarment PPE (inner layer) - mainly taking over the sensorial and thermophysiological comfort functions; outer layer - having a barrier function for the risk factors in the work environment (heat and flame, cold, bad weather, mechanical aggression, etc.); intermediate layer - encompassing the system of enabling the thermal insulation function

\section{Materials}

Functional clothing by definition is user-requirement specific and designed or engineered to meet the performance requirements of the user under extreme conditions. Protective - functional represents the largest and most diverse segment of functional clothing (Gupta, 2011). Development of functional fibers is based on the process of incorporating active chemicals into de fiber in its manufacturing stage, and this technology is rather increasing today, mainly being supported by fiber manufacturers. The functionalized fibers developed by Smartpolymer $\mathrm{GmbH}$ AG (Germany), through ALCERU procedure (the active substance: Paraffin/ Permethrin/Tocopherol, is directly integrated into the cellulose matrix imparting a permanent function to the cellulose) mixed with cotton fibers and /or modal fibers have been used to accomplish knitted fabrics for undergarment PPE.

As part of the project there were used: a) fibre Cell Solution CLIMA, a PCM (Phase Change Material) micro composite of the latest fiber manufacturing generation with thermoregulating features. Via a patented spinning process, paraffin is embedded in crystalline and tear resistant functional Lyocell fibers ${ }^{* * *}$ Cell Solution Clima); b) fibre Cell Solution PROTECTION - are natural cellulosic manmade fibers provide effective and durable protection against insects-such as

https://doi.org/10.24264/icams-2018.VI.12 
ticks and mosquito. Via direct spinning, the insect repellent permethrin is embedded in the Cell Solution fiber core and migrates to the fiber surface in a tightly controlled manner $(* * *$ Cell Solution Protection); c) fibre Cell Solution SKIN CARE - are Lyocell fibers with integrated natural oils and Vitamin E. By embedding a Vitamin E depot into the matrix structure a Cell Solution Skincare, the release of Vitamin E turns into a lifelong effect (*** Cell Solution Skin Care).

The knitted fabrics are made of different construction of yarns, as mentioned in table 1.

Table 1. Knitted fabrics yarns composition

\begin{tabular}{llll}
\hline $\begin{array}{l}\text { Fabric } \\
\text { code }\end{array}$ & $\begin{array}{l}\text { Yarn count } \\
(\mathrm{Nm})\end{array}$ & $\begin{array}{l}\text { Yarn } \\
\text { construction }(\%)\end{array}$ & Yarn composition \\
\hline T1 & $50 / 1$ & $60 / 20 / 20$ & Cotton/ Modal/ Cell Solution PROTECTION \\
T2 & $50 / 1$ & $60 / 20 / 20$ & Cotton/ Modal/ Cell Solution SKIN CARE \\
T3 & $50 / 1$ & $70 / 30$ & Cotton / Cell Solution CLIMA \\
\hline
\end{tabular}

Interlock weft knitted fabrics were produced for this research on a E20 Uniplet circular knitting machine. The knitted fabrics were subjected to finishing procedures. The pretreatment, in a single "gentle" step with a chemical agent especially designed for a low temperature bleaching process based on synergistic mixtures of specific non-ionic surfactants with superior wetting, emulsifying and removal properties of grease impurities, oils, accidental pigments, was carried out at a lower temperature than the boiling point and a reduce duration of approx. 110 minute compared to the traditional pretreatment process in successive phases.

Table 2 shows the physical-mechanical and physical - chemical characteristics of the weft knitted fabrics produced.

Table 2. Characteristics of the knitted fabrics

\begin{tabular}{lllll}
\hline Characteristics & \multicolumn{3}{l}{ Fabric code } \\
& $\mathrm{T} 1$ & $\mathrm{~T} 2$ & $\mathrm{~T} 3$ \\
\hline Weight, $\mathrm{g} / \mathrm{m}^{2}$ & & 262 & 247 & 276 \\
Density $10 \mathrm{~cm} \quad$ course no/horizontal & 151 & 146 & 140 \\
& row no./vertical & 152 & 141 & 161 \\
Thickness, $\mathrm{mm} \quad 0.99$ & 0.98 & 1.21 \\
Bursting strength, $\mathrm{kPa}$ & 344 & 350 & 327 \\
Bursting distension, $\mathrm{mm}$ & 39 & 38 & 47 \\
Abrasion resistance, cycles no. & 50604 & 53543 & 44330 \\
Air permeability, $\quad 1 / \mathrm{m}^{2} / \mathrm{s}$ & 413.6 & 417.8 & 427.8 \\
Water vapour resistance $\mathrm{Ret}, \mathrm{m}^{2} \mathrm{~Pa} / \mathrm{W}$ & 5.86 & 6.17 & 7.04 \\
Thermal resistance Rct, $\mathrm{m}^{2} \mathrm{~K} / \mathrm{W}$ & 0.0286 & 0.0255 & 0.0314 \\
\hline
\end{tabular}

Physical - mechanical and physical - chemical characteristics have been made on knitted fabrics, as follows: weight (SR EN 12127:2003), density (SR EN 14971:2006), thickness (SR EN ISO 5084:2001), burst strength and burst distension (EN ISO 13938-2:2003), abrasion resistance - Martindale method (SR EN ISO 12947-2:2017), air permeability (SR EN ISO 9237:1999), water - vapour resistance and thermal resistance (SR EN ISO 11092:2015). 


\section{Prototype Design}

There are a number of challenges for integration with respect to PPE: selecting and adapting materials for specific user and operational requirements; optimizing hybrid systems for protection, cost, weight, and human factors; developing concepts for mission - configurable systems; developing material system for multi- threat protection.

Principles that have been taken into account when designing an integrated prototype system of undergarments PPE are:

a) establishing the operating environment and operational requirements, which include identification of: clothing components (subsystems) of the PPE system; key performance parameters for each component garment (subsystem); any physical requirement for the component part of the PPE system or for the system; any requirement for interoperability and / or maintenance;

b) integration of protection with other functions: use of multifunctional materials, reducing weight and complexity of the PPE system through integration of functions;

c) human factors - factors that affect the comfort or effectiveness of the user and that have a critical effect on the performance of the wearer.

For undergarments PPE a two pieces garment configuration (long - sleeved shirt and full-length trousers; t-shirt and short trousers) was designed and manufactured (Figure 1).

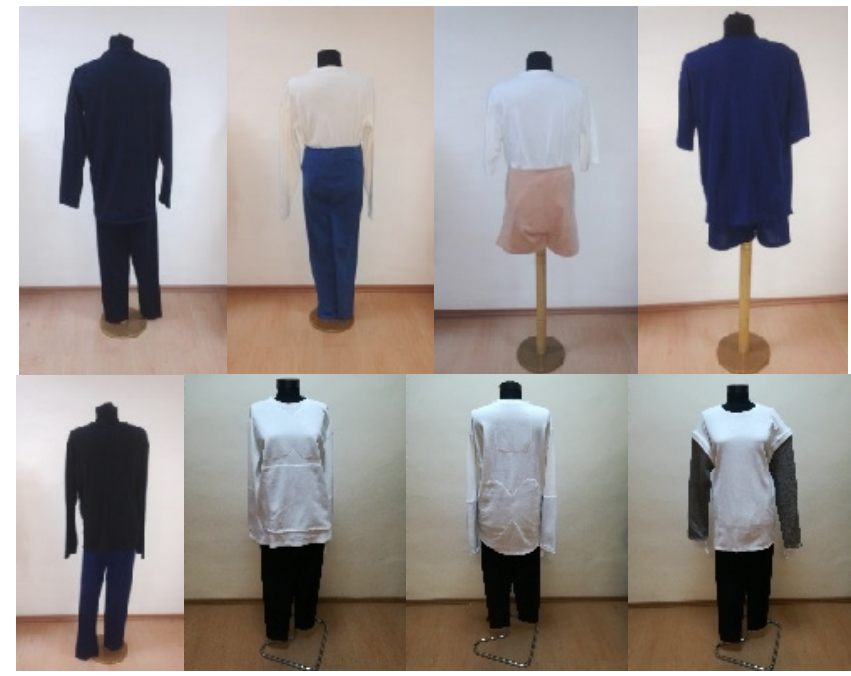

Figure 1. Prototypes of undergarments PPE with modular structure

To ensure the performance requirements imposed there were considered the following technological design features of the PPE: a) use of technologies with fewer operations due to: fully tailored details; transfer of tucks into the constructive lines, providing also a degree of freedom in specific movements; b) selecting the correct fineness of sewing needles and thread depending on the structural features 
of the knitted fabric and the type of ensemble; c) appropriate selection of the types of machinery and ensembles that would provide high standards on the stitch resistance.

\section{RESULTS AND DISCUSSIONS}

The analysis of the results obtained in performing specific laboratory tests for the knitted fabrics (T1,T2 and T3) of the undergarments PPE, highlights the following:

- bursting strengths with values of over $300 \mathrm{kPa}$ combined with busting distension above $38 \mathrm{~mm}$ meet the minimum values required by the applicable product specifications in the military field (min. $160 \mathrm{kPa}$ ), respectively the minimum limits imposed by the PPE specific standards for knitted fabrics used as outer layer of the PPE (min. $200 \mathrm{kPa}$ );

- air permeability has values above the minimum required by the technical product specifications applicable to defense / public order / security (min. 200 1/ $\mathrm{m}^{2} / \mathrm{s}$ );

- water - vapour resistance has comparable values between the knitted fabrics $\left(5.86-7.04 \mathrm{~m}^{2} \mathrm{~Pa} / \mathrm{W}\right)$, correlated with the percentage of functional fibers in the fiber mixture, meet the maximum imposed limit of $55 \mathrm{~m}^{2} \mathrm{~Pa} / \mathrm{W}$ (for cold protective clothing) and maximum $30 \mathrm{~m}^{2} \mathrm{~Pa} / \mathrm{W}$ for performance level 2 of firefighting clothing;

- good behavior in wearing appreciated through the abrasion resistance values of over 40000 cycles.

\section{CONCLUSIONS}

The aim of this research was to develop functional undergarments equipment, designed to be integrated in specialized protection equipment systems, in order to ensure the survival and resistance of operational staff from the defense, public order, security structures, in variable conditions of temperature, activity and weight levels of the equipment carried.

To meet this objective new textile knitted structures have been developed by using the functional cellulose fibers Cell Solution CLIMA, Cell Solution PROTECTION and Cell Solution SKIN CARE, mixed with cotton fibers and /or modal fibers being design and manufacture of undergarments PPE prototypes with modular structure.

The testing and evaluation process consisted of objective and subjective testing.

The objective laboratory testing of knitted fabrics validated the material performance and ensured compliance to standards requirements. However, laboratory data cannot accurately assess the operational suitability and effectiveness of a PPE system when used under operating conditions. Critical attributes, such as comfort, appearance, durability, freedom, and range of motion, could not fully evaluate under laboratory conditions.

The user's subjective perception for the operational suitability and effectiveness of the PPE system is determined by conducting a Wear Trial of the undergarments PPE which are integrated in specialized equipment. This subjective evaluation proves the essential difference of the performance of the various fabrics manufactured into the garments. Most importantly the operational assessment provide the feedback on the functionality of the PPE garment design. 
Acknowledgement

This work was supported by a grant of the Romanian National Authority for Scientific Research and Innovation, CNCS/CCCDI, project number PN-III-P2-2.1PTE-2016-0041, within PNCDI III

\section{REFERENCES}

Gupta, D. (2011), "Functional clothing - Definition and classification", Indian Journal of Fibre \& Textile Research, 36, 321-326.

Royal, M. and Jennings, D. (2014), "Project Responder 42014 National Technology Plan for Emergency Response to Catastrophic Incidents", Homeland Security Studies and Analysis Institute, RP13-17-02, 89100.

*** Soldier Systems Technology Roadmap 2011-2025 (SSTRM) - Capstone Report and Action Plan, 2010.

$* * * \mathrm{http}: / / \mathrm{www}$. cellsolution.eu/products/cell-solution-climafiber/

$* * * \mathrm{http}: / / \mathrm{www}$. cellsolution.eu/products/cell-solution-protection/

*** http://www.cellsolution.eu/products/cell-solution-skin-care/ 